\title{
Syntheses and structural characterization of dicopper(I) bis(diphenylphosphino)acetylene complexes containing tricyclic, cyclic and linear frameworks
}

\author{
Yu-Chiao Liu ${ }^{\text {a }}$, Ching-I Li ${ }^{\text {a }}$, Wen-Yann Yeh ${ }^{\text {a,* }}$, Gene-Hsiang Lee ${ }^{\text {b }}$, Shie-Ming Peng ${ }^{b}$ \\ a Department of Chemistry, National Sun Yat-Sen University, 70 Lien-Hai Road, Kaohsiung 804, Taiwan \\ b Department of Chemistry, National Taiwan University, Taipei 106, Taiwan
}

Received 31 October 2005; received in revised form 22 February 2006; accepted 23 February 2006

Available online 3 March 2006

\begin{abstract}
The complexes $\left[\mathrm{Cu}_{2}(\mathrm{dppa})_{3}\left(\mathrm{CH}_{3} \mathrm{CN}\right)_{2}\right]\left[\mathrm{BF}_{4}\right]_{2}$ (1) and $\mathrm{Cu}_{2}(\mathrm{dppa})_{3}\left(\mathrm{O}_{3} \mathrm{SCF}_{3}\right)_{2}(2)$ have been prepared in good yields by treating $\left[\mathrm{Cu}(\mathrm{MeCN})_{4}\right]\left[\mathrm{BF}_{4}\right]$ and $\left[\mathrm{Cu}(\mathrm{MeCN})_{4}\right]\left[\mathrm{O}_{3} \mathrm{SCF}_{3}\right]$, respectively, with $\mathrm{Ph}_{2} \mathrm{PC} \equiv \mathrm{CPPh}_{2}($ abbreviated as dppa) at room temperature. The reaction of 1 with di-2-pyridyl ketone (abbreviated as dpyk) produces $\left[\mathrm{Cu}_{2}(\mathrm{dppa})_{2}(\mathrm{dpyk})_{2}\right]\left[\mathrm{BF}_{4}\right]_{2}(3)$, and with $1,1^{\prime}$-bis(diphenylphosphino)ferrocene (abbreviated as dppf) produces $\left[\mathrm{Cu}_{2}(\mathrm{dppa})(\mathrm{dppf})_{2}\right]\left[\mathrm{BF}_{4}\right]_{2}(\mathbf{4})$. The molecular structures of $\mathbf{1}-\mathbf{4}$ have been determined by an X-ray diffraction study. Compounds 1 and $\mathbf{2}$ form a helical $\mathrm{Cu}_{2}(\mathrm{dppa})_{3}$ metallatricycle, compounds $\mathbf{3}$ forms a $\mathrm{Cu}_{2}(\mathrm{dppa})_{2}$ metallacycle, and compound $\mathbf{4}$ contains a linear $\mathrm{Cu}_{2}$ (dppa) skeleton.
\end{abstract}

(c) 2006 Elsevier B.V. All rights reserved.

Keywords: Dicopper(I) complexes; Bis(diphenylphosphino)acetylene; 1,1'-Bis(diphenylphosphino)ferrocene

\section{Introduction}

The 'coordination clusters' assembling from monometallic complexes and multidentate bridging ligands have received much attention due to their potential applications in catalysis, molecular recognition and photoactive device [1-6]. Recently, interest in the design and synthesis of discrete copper cluster complexes was stimulated by the structural elucidation of several di-, tri- and tetranuclear copper centers in biologically active molecules [7-9]. Bis(diphenylphosphino)acetylene (abbreviated as dppa) is a potentially trifunctional ligand, where the two phosphorus centers are normally coordinated to metals in advance of the acetylene group due to stronger net donor capability of the phosphine ligand compared with alkyne [10]. However, the rigidity of the linear

\footnotetext{
* Corresponding author. Tel.: +886 7 5252000; fax: +886 75253908.

E-mail address: wenyann@mail.nsysu.edu.tw (W.-Y. Yeh).
}

$-\mathrm{C} \equiv \mathrm{C}-$ backbone constrains the dppa ligand to bridge between metal centers, forming either dimeric or polymeric coordination compounds [11-15]. We previously reported the preparation and reactivity of a tris(dppa) ditungsten complex [16]. In this paper, we present the syntheses and characterization of four new dinuclear $\mathrm{Cu}(\mathrm{I})$ complexes bridged by three, two and one dppa ligands.

\section{Results and discussion}

The reaction of $\left[\mathrm{Cu}(\mathrm{MeCN})_{4}\right]\left[\mathrm{BF}_{4}\right]$ and dppa ligand in a $2: 3$ ratio has been carried out at room temperature to afford $\left[\mathrm{Cu}_{2}(\mathrm{dppa})_{3}\left(\mathrm{CH}_{3} \mathrm{CN}\right)_{2}\right]\left[\mathrm{BF}_{4}\right]_{2}(\mathbf{1})$ in $93 \%$ yield after crystallization. In contrast, the analogous reaction of $\left[\mathrm{Cu}(\mathrm{MeCN})_{4}\left[\mathrm{O}_{3} \mathrm{SCF}_{3}\right]\right.$ with dppa produces $\mathrm{Cu}_{2}(\mathrm{dppa})_{3^{-}}$ $\left(\mathrm{O}_{3} \mathrm{SCF}_{3}\right)_{2}(2)$ in $98 \%$ yield, of which the trifluorosulfonate counter anion is bonded to each copper(I) center through the oxygen atom. Compounds $\mathbf{1}$ and $\mathbf{2}$ consist of two copper(I) atoms bridged by three dppa ligands, while the 
former contains two labile acetonitrile species susceptible to further ligand substitution. It is of interest to investigate the reactivity of 1 towards bidentate ligands to see whether the $\mathrm{M}_{2} \mathrm{~L}_{3}$ cage framework is affected. Thus, compound $\mathbf{1}$ is treated with di-2-pyridyl ketone (abbreviated as dpyk) at room temperature to produce $\left[\mathrm{Cu}_{2}(\mathrm{dppa})_{2}(\mathrm{dpyk})_{2}\right]\left[\mathrm{BF}_{4}\right]_{2}$ (3) in 97\% yield, concomitant with elimination of one dppa bridge. On the other hand, the reaction of 1 with the diphosphine ligand 1,1'-bis(diphenylphosphino)ferrocene (abbreviated as dppf) results in $\left[\mathrm{Cu}_{2}(\mathrm{dppa})(\mathrm{dppf})_{2}\right]\left[\mathrm{BF}_{4}\right]_{2}$ (4) in $85 \%$ yield, which contains only one dppa bridge between the two $[\mathrm{Cu}(\mathrm{dppf})]^{+}$moieties. The reactions are summarized in Scheme 1. Elimination of dppa bridges to give $\mathbf{3}$ and $\mathbf{4}$ may be attributed to chelating effects by the dpyk and dppf ligands. Previously, the importance of steric constraints in $\left[\mathrm{Cu}\left(\mathrm{PR}_{3}\right)_{3}\right]^{+}$complexes was well established $[17,18]$. So it is likely for the copper atoms in $\mathbf{4}$ to adopt a trigonal configuration for steric reasons. In contrast, the planar dpyk ligand is less space-congested that the tetrahedral coordination retained for 3 .
Compounds 1 and $\mathbf{2}$ form air-stable, colorless crystals. The FAB mass spectrum of $\mathbf{1}$ shows the molecular cation peak at $m / z 654(z=2)$ for ${ }^{63} \mathrm{Cu}$, and the ESI mass spectrum of 2 displays the ion peak at $\mathrm{m} / z 1457$ corresponding to the $\mathrm{M}^{+}-\mathrm{O}_{3} \mathrm{SCF}_{3}$ fragment. The ${ }^{1} \mathrm{H}$ NMR of 1 presents a multiplet in the range $\delta 7.43-7.11$ for the phenyl protons and a singlet at $\delta 2.61$ for the methyl protons, while only a multiplet in the range $\delta 7.55-7.08$ is recorded for 2 . The ${ }^{31} \mathrm{P}\left\{{ }^{1} \mathrm{H}\right\}$ NMR spectra of $\mathbf{1}$ and $\mathbf{2}$ are comparable, showing a broad signal at $\delta-26.70$ and -28.21 , respectively. The spectral data are in agreement with a $D_{3}$ symmetry for $\mathbf{1}$ and $\mathbf{2}$ in solution.

The structure of 1 contains discrete cations $\left[\mathrm{Cu}_{2}(\mathrm{dp}-\right.$ pa) $\left.{ }_{3}\left(\mathrm{CH}_{3} \mathrm{CN}\right)_{2}\right]^{2+}$, tetrafluoroborate counter anions and solvent molecules. The ORTEP drawing for the cation is depicted in Fig. 1, which consists of two $(\mathrm{MeNC}) \mathrm{Cu}^{+}$ groups bridged by three dppa ligands. The coordination about the $\mathrm{Cu}^{+}$ion can be described as a distorted tetrahedral, such that the $\mathrm{P}-\mathrm{Cu}-\mathrm{P}$ angles range from $103.01(4)^{\circ}$ to $116.85(4)^{\circ}$ and the $\mathrm{N}-\mathrm{Cu}-\mathrm{P}$ angles range from $108.8(1)^{\circ}$ to
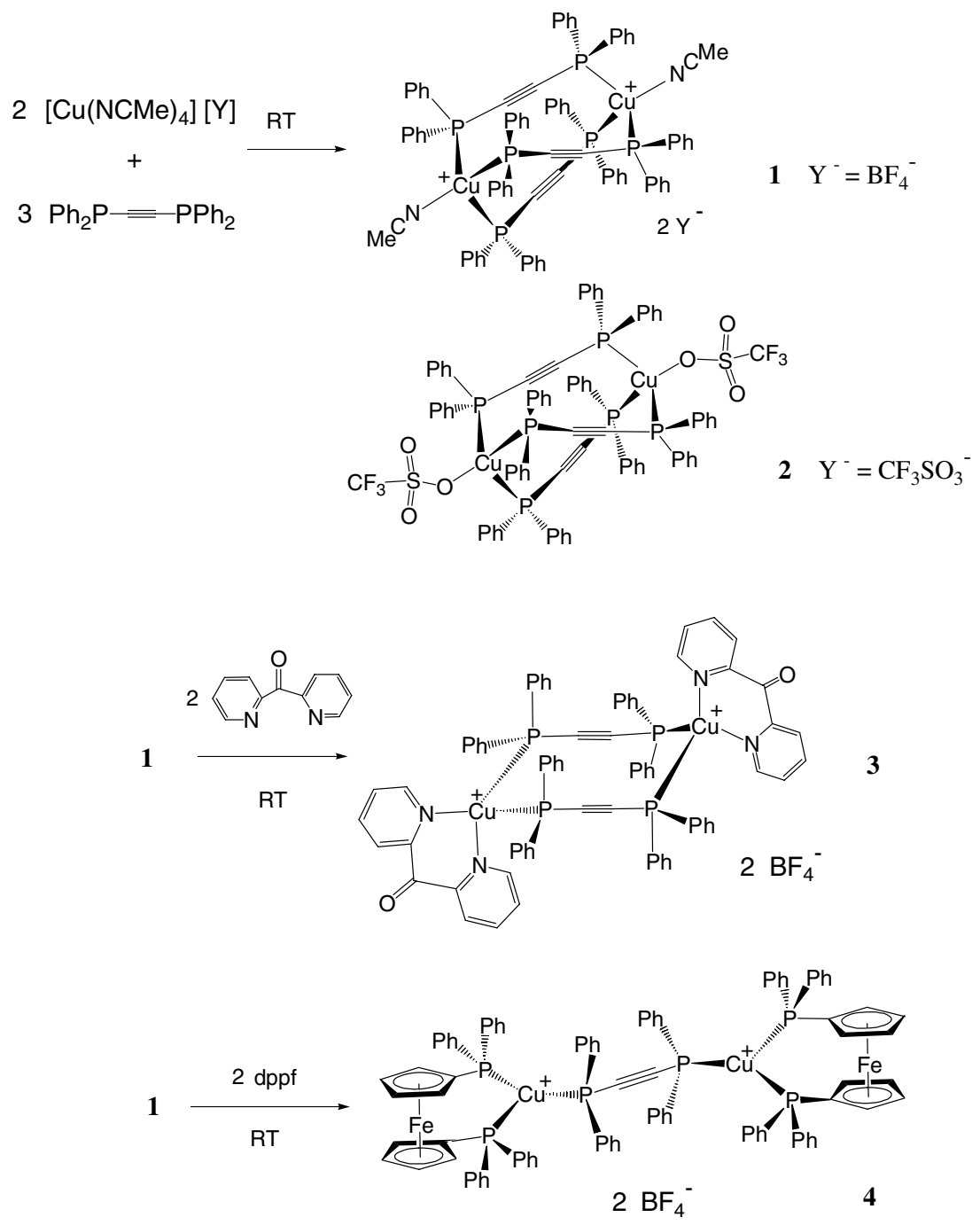

Scheme 1. 


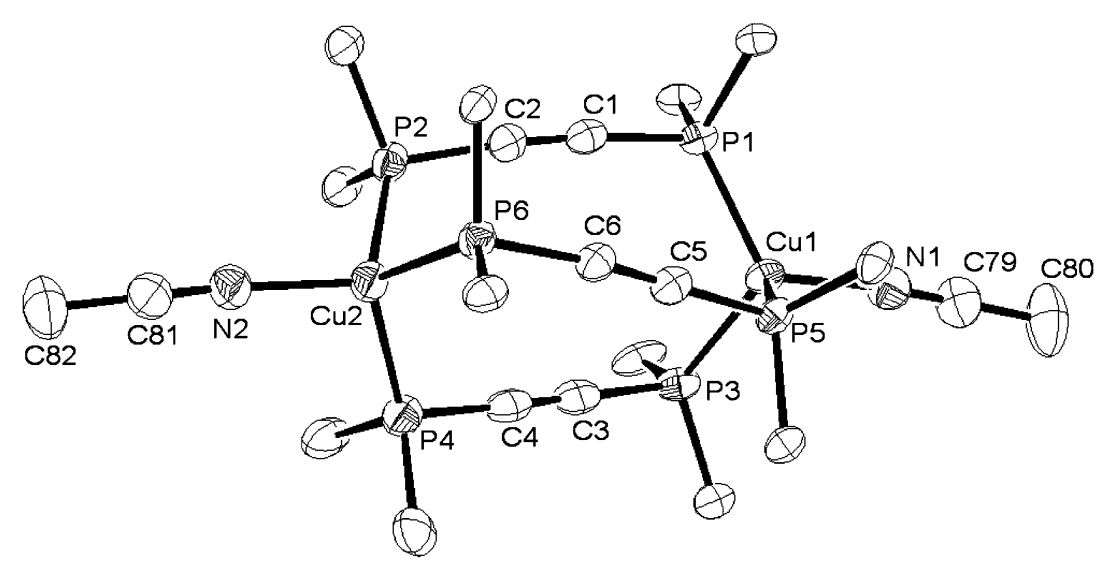

Fig. 1. Molecular structure of 1 . The $\mathrm{BF}_{4}{ }^{-}$anions have been artificially omitted. Only the ipso carbons of the $\mathrm{C}_{6} \mathrm{H}_{5}$ groups are shown for clarity. Selected bond distances $(\AA)$ and angles $\left({ }^{\circ}\right)$ : Cu1-N1 1.978(4), Cu2-N2 1.988(4), Cu1-P1 2.283(1), Cu1-P3 2.276(1), Cu1-P5 2.287(1), Cu2-P2 2.300(1), Cu2-P4 2.283(1), Cu2-P6 2.285(1), C1-C2 1.201(5), C3-C4 1.211(6), C5-C6 1.212(5); and P1-Cu1-P3 109.72(4), P1-Cu1-P5 111.07(4), P3-Cu1-P5 105.22(4), N1-Cu1-P1 115.6(1), N1-Cu1-P3 108.6(1), N1-Cu1-P5 106.2(1), Cu1-P1-C1 109.9(1), Cu1-P3-C3 108.2(1), Cu1-P5-C5 114.4(1), P1-C1-C2 174.2(3), P3-C3-C4 175.3(4), P5-C5-C6 176.9(3), P2-Cu2-P4 104.73(5), P2-Cu2-P6 103.01(4), P4-Cu2-P6 116.85(4), N2-Cu2-P2 110.8(1), N2-Cu2-P4 108.8(1), N2-Cu2-P6 112.2(1), Cu2-P2-C2 113.8(1), Cu2-P4-C4 112.2(1), Cu2-P6-C6 107.3(1), P2-C2-C1 175.0(3), P4-C4-C3 176.8(4), P6-C6-C5 173.1(3).

$115.6(1)^{\circ}$. The $\mathrm{Cu}-\mathrm{P}-\mathrm{C}_{\text {(acetylene) }}$ angles show a slight deviation from the ideal tetrahedral with angles ranging from $108.2(1)^{\circ}$ to $114.4(1)^{\circ}$. The $\mathrm{P}-\mathrm{C} \equiv \mathrm{C}-\mathrm{P}$ backbones are slightly bowed as indicated by the $\mathrm{P}-\mathrm{C} \equiv \mathrm{C}$ angles (average $\left.175.2^{\circ}\right)$, consistent with steric strains arising from the $\mathrm{M}_{2} \mathrm{~L}_{3}$-type cage arrangement. The complex can be treated like three-bladed propellers, shown in Fig. 2, by looking down the $\mathrm{Cu} 1 \cdots \mathrm{Cu} 2$ axis. There is a helical twist of ca. $18.6^{\circ}$ by taking the average of the torsional angles: P1$\mathrm{Cu} 1-\mathrm{Cu} 2-\mathrm{P} 218.2^{\circ}, \mathrm{P} 3-\mathrm{Cu} 1-\mathrm{Cu} 2-\mathrm{P} 416.9^{\circ}$ and P5-Cu1-

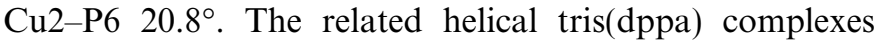
are $\quad \mathrm{Ni}_{2}(\mathrm{CO})_{2}(\mathrm{dppa})_{3} \quad[19], \quad \mathrm{Mo}_{2}(\mathrm{CO})_{6}(\mathrm{dppa})_{3} \quad[14]$ $\mathrm{W}_{2}(\mathrm{CO})_{6}(\mathrm{dppa})_{3}[16], \mathrm{Cu}_{2}(\mathrm{X})_{2}(\mathrm{dppa})_{3}\left(\mathrm{X}=\mathrm{TeBu}, \mathrm{SSiMe}_{3}\right)$ $[20,21],\left[\mathrm{Ag}_{2}(\mathrm{dppa})_{3}\right]^{+}[22]$ and $\mathrm{Au}_{2}(\mathrm{dppa})_{3} \mathrm{Cl}_{2}[23]$.

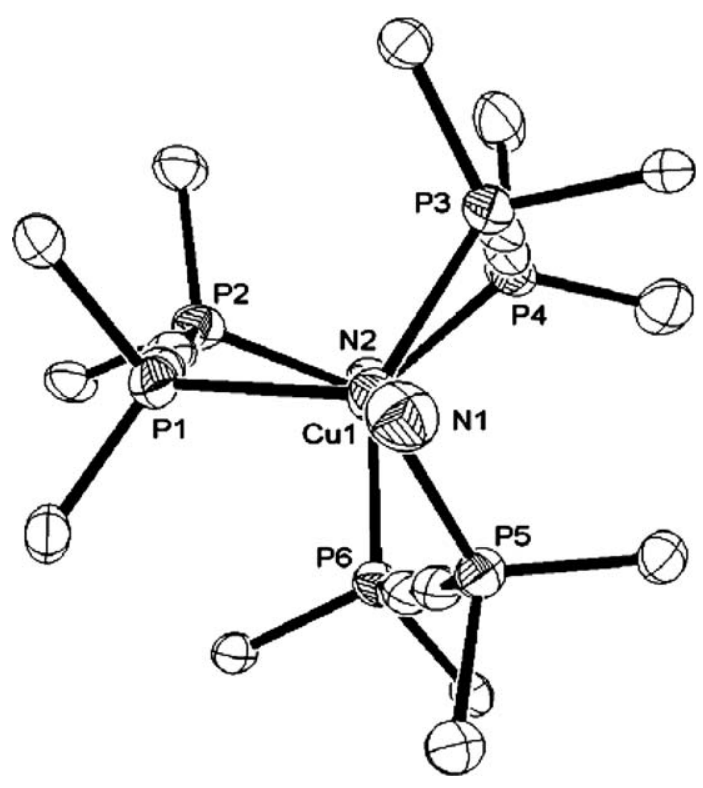

Fig. 2. Projection of compound $\mathbf{1}$ down the $\mathrm{Cu} 1-\mathrm{Cu} 2$ axis to show a helical $\mathrm{M}_{2} \mathrm{~L}_{3}$ arrangement for the dppa ligands.
The molecular structure of 2, depicted in Fig. 3, is closely resemblant to $\mathbf{1}$, except that a trifluorosulfonate group is coordinated to each copper center through the oxygen atom. The $\mathrm{P}-\mathrm{Cu} 1-\mathrm{P}$ angles range from $106.17(2)^{\circ}$ to $113.51(2)^{\circ}$ and the $\mathrm{O} 1-\mathrm{Cu} 1-\mathrm{P}$ angles range from $101.30(5)^{\circ}$ to $115.68(5)^{\circ}$. The $\mathrm{Cu} 1-\mathrm{O} 1-\mathrm{S} 1$ angle of $132.1(1)^{\circ}$ is substantially larger than the idealized bond angle of $109.5^{\circ}$, likely due to repulsions between the phenyl and $\mathrm{CF}_{3}$ groups. The helical twist for the $\mathrm{Cu}_{2}(\mathrm{dppa})_{3}$ skeleton is $16.4^{\circ}$ by taking the average of the torsional angles: $\mathrm{P} 1-\mathrm{Cu} 1-\mathrm{Cu} 1 \mathrm{~A}-\mathrm{P} 213.6^{\circ}, \mathrm{P} 2 \mathrm{~A}-\mathrm{Cu} 1-\mathrm{Cu} 1 \mathrm{~A}-\mathrm{P} 1 \mathrm{~A} 13.6^{\circ}$ and $\mathrm{P} 3-\mathrm{Cu} 1-\mathrm{Cu} 1 \mathrm{~A}-\mathrm{P} 3 \mathrm{~A} 22.0^{\circ}$. The $\mathrm{P}-\mathrm{C} \equiv \mathrm{C}-\mathrm{P}$ backbones are slightly bowed by the angles $\mathrm{P} 1-\mathrm{C} 1-\mathrm{C} 2178.8(2)^{\circ}, \mathrm{P} 2-$ C2-C1 175.6(2) ${ }^{\circ}$ and P3-C3-C3A 174.2(2) ${ }^{\circ}$.

The ORTEP drawing for the cation of $\mathbf{3}$ is depicted in Fig. 4. There is a crystallographic center of symmetry imposed on the molecule. Each $\mathrm{Cu}(\mathrm{I})$ atom is chelated by a dpyk ligand, and the two $\mathrm{Cu}(\mathrm{dpyk})$ groups are bridged by two dppa ligands. The $\mathrm{Cu}^{+}$ion adopts a distorted tetrahedral coordination, with the bond angles ranging from $93.52(9)^{\circ}$ for the $\mathrm{N} 1-\mathrm{Cu}-\mathrm{N} 2$ bite to $122.21(6)^{\circ}$ for the $\mathrm{P} 1-\mathrm{Cu}-\mathrm{N} 2$ link. The $\mathrm{Cu}(\mathrm{dpyk})$ unit is envelope-like, where the $\mathrm{N} 2, \mathrm{C} 7, \mathrm{C} 6, \mathrm{O} 1$ and $\mathrm{C} 5$ atoms are planar to within $0.01 \AA$ and the $\mathrm{N} 1$ and $\mathrm{Cu}$ atoms are 0.21 and $0.76 \AA$ above the plane. The dihedral angle between the two pyridyl planes is $14.8^{\circ}$. The arrangement for the $\mathrm{Cu}_{2}(\mathrm{dppa})_{2}$ moiety can be considered as a 10 -membered chair-like dimetallacycle. The P1, P2, C12 and $\mathrm{C} 25$ atoms are coplanar to within $0.01 \AA$ and the $\mathrm{Cu}$ atoms are $1.05 \AA$ away from the plane. The $\mathrm{P} 1-\mathrm{Cu}-\mathrm{P} 2$ plane makes a dihedral angle of $60.2^{\circ}$ and $85.5^{\circ}$ with the $\mathrm{P} 1-\mathrm{P} 2-\mathrm{C} 12-\mathrm{C} 25$ plane and the $\mathrm{N} 1-\mathrm{Cu}-\mathrm{N} 2$ plane, respectively. The C5-C6-C7 angle is $126.4(2)^{\circ}$ and the $\mathrm{P}-\mathrm{C} \equiv \mathrm{C}$ angles are bowed by $6^{\circ}$ in average from the idealized $180^{\circ}$.

Compound 3 forms an air-stable, bright yellow crystalline solid. The FAB mass spectrum displays the molecular cation peak at $m / z 641(z=2)$. Interestingly, even though 


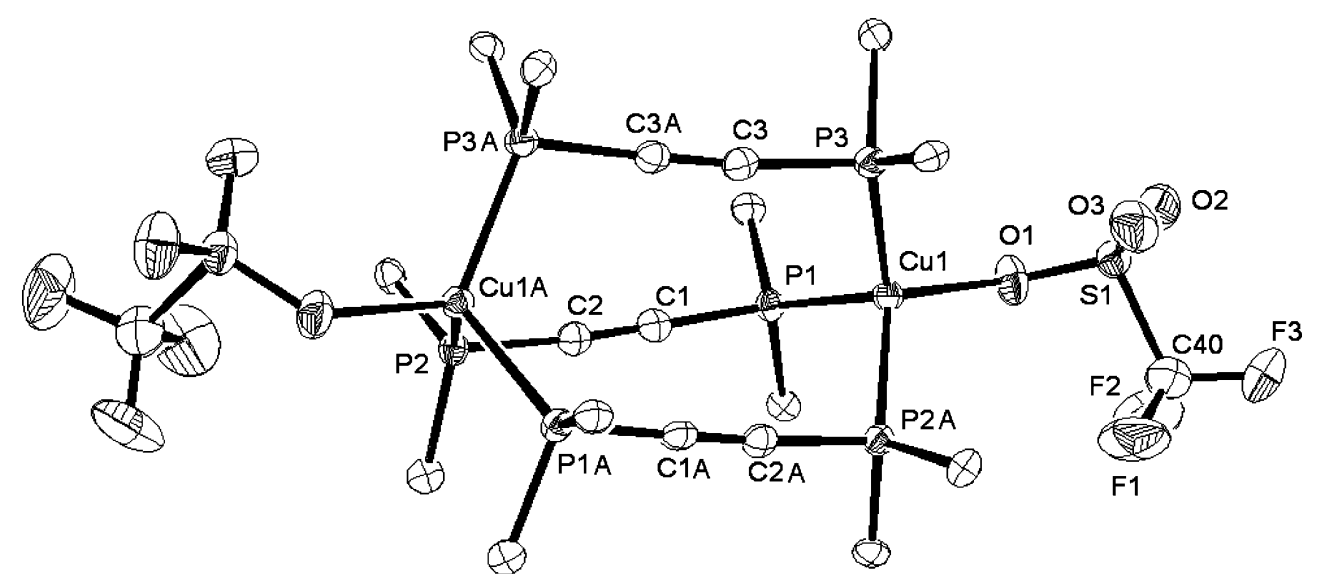

Fig. 3. Molecular structure of 2. Only the ipso carbons of the $\mathrm{C}_{6} \mathrm{H}_{5}$ groups are shown for clarity. Selected bond distances $(\AA)$ and angles $\left({ }^{\circ}\right)$ : $\mathrm{Cu} 1-\mathrm{P} 1$ 2.2978(6), Cu1-P2A 2.2830(6), Cu1-P3 2.2697(6), Cu1-O1 2.106(2), S1-O1 1.456(2), S1-O2 1.419(2), S1-O3 1.434(2), C1-C2 1.206(3), C3-C3A 1.183(4); and P1-Cu1-P2A 106.17(2), P1-Cu1-P3 113.51(2), P3-Cu1-P2A 109.22(2), O1-Cu1-P1 101.30(5), O1-Cu1-P2A 115.68(5), O1-Cu1-P3 110.79(5), Cu1O1-S1 132.1(1), Cu1-P1-C1 111.85(8), Cu1-P2A-C2A 106.88(8), Cu1-P3-C3 104.10(7), P1-C1-C2 178.8(2), P2-C2-C1 175.6(2), P3-C3-C3A 174.2(2).

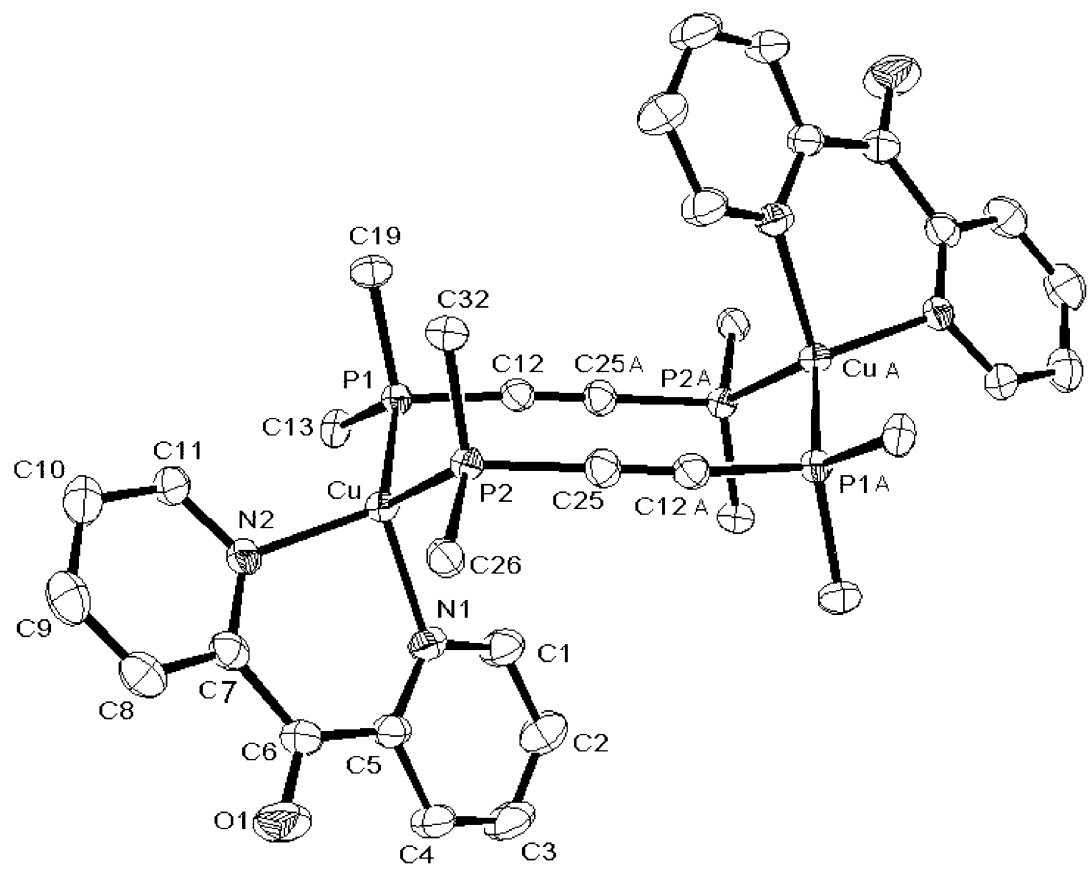

Fig. 4. Molecular structure of 3. The $\mathrm{BF}_{4}{ }^{-}$anions have been artificially omitted. Only the ipso carbons of the $\mathrm{C}_{6} \mathrm{H}_{5}$ groups are shown for clarity. Selected bond distances $(\AA)$ and angles $\left({ }^{\circ}\right)$ : $\mathrm{Cu}-\mathrm{N} 1$ 2.040(2), Cu-N2 2.029(2), Cu-P1 2.2256(7), Cu-P2 2.2561(7), C12-C25A 1.201(4); and P1-Cu-P2 114.27(3), $\mathrm{P} 1-\mathrm{Cu}-\mathrm{N} 1$ 112.43(7), P1-Cu-N2 122.21(6), P2-Cu-N1 107.94(6), P2-Cu-N2 104.02(6), N2-Cu-N1 93.52(9), Cu-P1-C12 108.97(9), Cu-P2-C25 112.38(9), P1-C12-C25A 174.1(2), P2-C25-C12A 173.9(2), C5-C6-C7 126.4(2).

the two pyridyl groups are inequivalent (endo and exo), only one set of proton resonances are recorded down to $-80{ }^{\circ} \mathrm{C}$. The ${ }^{1} \mathrm{H}$ NMR spectrum at $-60^{\circ} \mathrm{C}$ is shown in Fig. 5, where the pyridyl protons are assigned on the basis of coupling pattern, and the triplet at $\delta 7.48$ and the multiplet at $\delta 7.25-7.14$ are attributed to the phenyl protons. Coincidence of the two pyridyl resonances is likely a result of accidental overlap, or a dynamic equilibrium involving fast flipping of the chair-like skeleton [24]. The ${ }^{13} \mathrm{C}\left\{{ }^{1} \mathrm{H}\right\}$ spectrum is displayed in Fig. 6. The quaternary carbon signals at $\delta 172.9$ (for $C-\mathrm{O}$ ), 142.2 (for $C-\mathrm{CO}$ ), 117.7 (a dou- blet with $J_{\mathrm{P}-\mathrm{C}}=42 \mathrm{~Hz}$ for $C_{(\mathrm{Ph})}-\mathrm{P}$ ) and 91.4 (for $C \equiv$ ) are assigned by comparing to the DEPT-edited spectrum shown above. The signals at $\delta$ 139.1, 129.8, 118.4 and 117.7 in about equal intensity can be assigned to the pyridyl carbons, and the remaining signals are attributed to the phenyl carbons.

Compound 4 forms air-stable, orange crystals. The FAB and ESI mass spectra display the highest ion peak at $\mathrm{m} / \mathrm{z}$ 1011 , corresponding to the species $[\mathrm{Cu}(\mathrm{dppa})(\mathrm{dppf})]^{+}$or $\left[\mathrm{Cu}_{2}(\mathrm{dppa})_{2}(\mathrm{dppf})_{2}\right]^{+2}$. However, a stoichiometry with the $\mathrm{Cu}$ :dppa:dppf ratio of $2: 1: 2$ is suggested by the elemental 


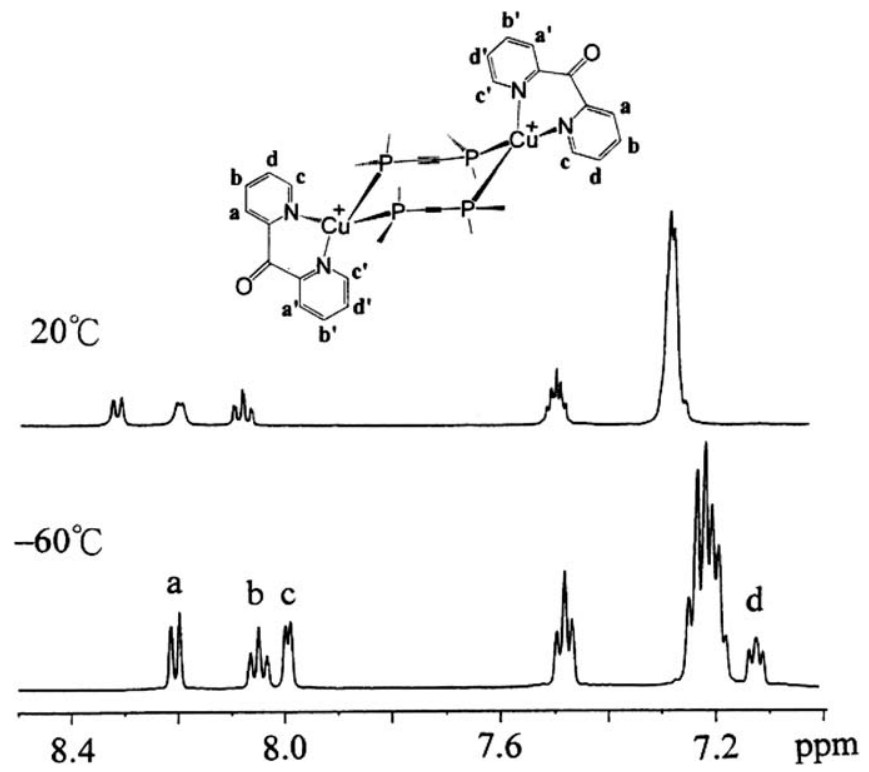

Fig. 5. ${ }^{1} \mathrm{H}$ NMR spectra of compound 3 in $\mathrm{CD}_{2} \mathrm{Cl}_{2}$.

analysis and ${ }^{1} \mathrm{H}$ NMR spectrum, which shows a $60 \mathrm{H}$ multiplet in the range $\delta 7.45-7.26$ for the phenyl protons, and two $8 \mathrm{H}$ doublets $\left(J_{\mathrm{H}-\mathrm{H}}=8 \mathrm{~Hz}\right)$ at $\delta 4.37$ and 4.14 for the Cp protons. The variable-temperature ${ }^{31} \mathrm{P}\left\{{ }^{1} \mathrm{H}\right\}$ NMR spectra are presented in Fig. 7 . At $25^{\circ} \mathrm{C}$, the two broad signals

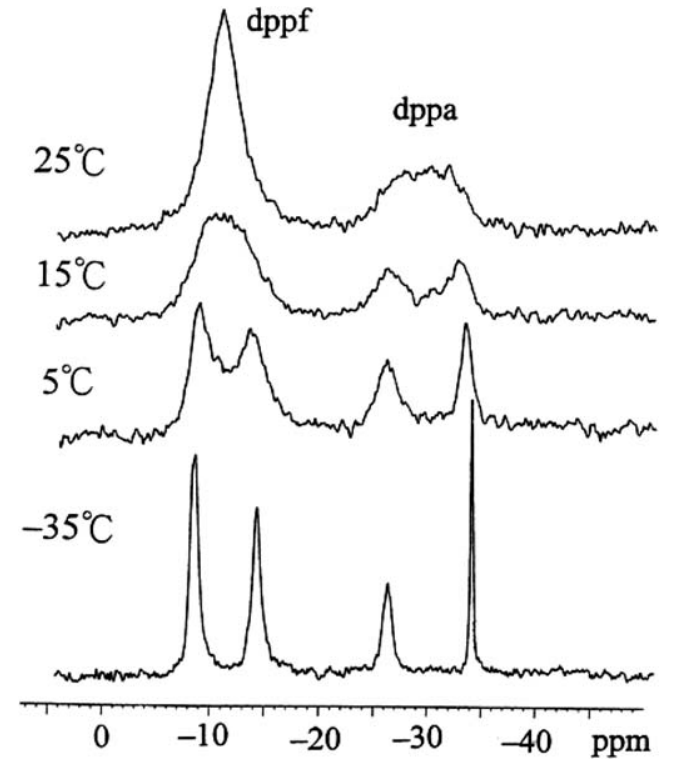

Fig. 7. Variable-temperature ${ }^{31} \mathrm{P}\left\{{ }^{1} \mathrm{H}\right\}$ NMR spectra of compound 4 in $\mathrm{CD}_{2} \mathrm{Cl}_{2}$.

at $\delta-10.4$ and -31.0 are assigned to the dppf and dppa ligands, respectively. At lower temperatures, they collapse and emerge as two sets of resonances at $\delta-7.78$ and -13.29 for dppf and at $\delta-25.15$ and -33.03 for dppa

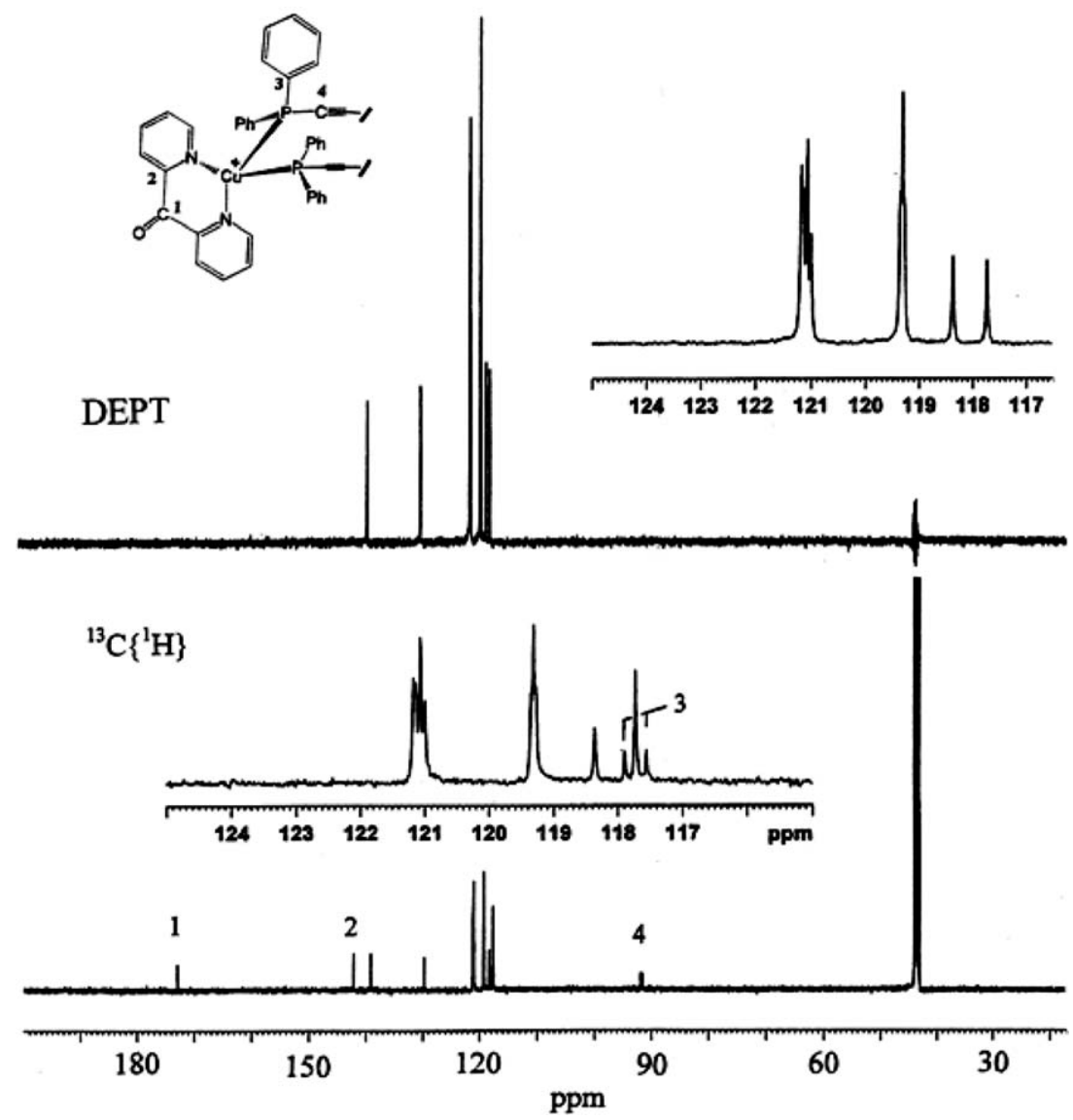

Fig. 6. ${ }^{13} \mathrm{C}\left\{{ }^{1} \mathrm{H}\right\}$ NMR and DEPT-edited (for $\mathrm{CH}$ groups) spectra of compound 3 in $\mathrm{CD}_{2} \mathrm{Cl}_{2}$ at $-70{ }^{\circ} \mathrm{C}$. 


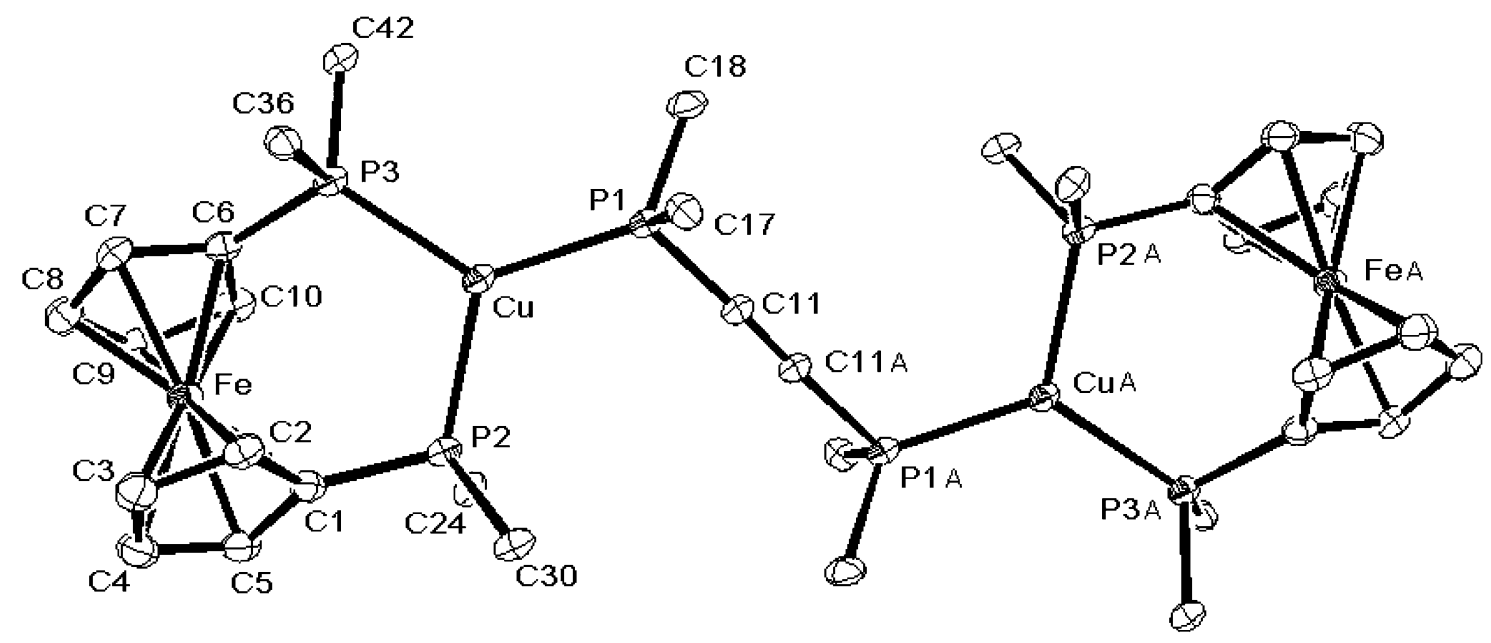

Fig. 8. Molecular structure of 4. The $\mathrm{BF}_{4}{ }^{-}$anions have been artificially omitted. Only the ipso carbons of the $\mathrm{C}_{6} \mathrm{H}_{5}$ groups are shown for clarity. Selected bond distances $(\AA)$ and angles $\left({ }^{\circ}\right)$ : Cu-P1 2.252(1), Cu-P2 2.265(1), Cu-P3 2.263(1), C11-C11A 1.194(8); P1-Cu-P2 120.14(4), P1-Cu-P3 127.68(4), P3$\mathrm{Cu}-\mathrm{P} 2$ 112.14(4), Cu-P3-C6 113.3(1), Cu-P2-C1 114.2(1), Cu-P1-C11 115.2(1), P1-C11-C11A 176.6(6).

ligands. These data suggest a dynamic equilibrium between two comformers in solution. Because of the absence of diagnostic spectral features to reveal the structure of $\mathbf{4}$, a single-crystal X-ray diffraction study was performed.

The crystal of 4 contains discrete cations $\left[\mathrm{Cu}_{2}(\mathrm{dp}\right.$ pa) $\left.(\text { dppf })_{2}\right]^{2+}$ and tetrafluoroborate counter anions. The ORTEP drawing for the cation is illustrated in Fig. 8. There is a crystallographic center of symmetry imposed on the molecule. Each $\mathrm{Cu}$ atom is chelated by a dppf ligand, and the two $\mathrm{Cu}(\mathrm{dppf})$ groups are bridged by one dppa ligand. The $\mathrm{Cu}$ atom is nominally three-coordinate. With the P1, P2 and P3 atoms forming the basal trigonal plane, the interligand bond angles surrounding the $\mathrm{Cu}$ atom are within $8^{\circ}$ of the trigonal expectation of $120^{\circ}$; the three angles sum to $360^{\circ}$, consistent with the small displacement of the $\mathrm{Cu}$ atom from the basal trigonal plane $(0.02 \AA)$. The $\mathrm{Cu}, \mathrm{P} 1, \mathrm{P} 1 \mathrm{~A}$ and $\mathrm{CuA}$ atoms are planar, which makes a dihedral angle of $33.0^{\circ}$ with the $\mathrm{P} 2-\mathrm{Cu}-$ $\mathrm{P} 3$ plane. The two $\mathrm{Cp}$ rings are about parallel, with a dihedral angle of $1.5^{\circ}$, and the $\mathrm{C} 1-\mathrm{P} 2$ and $\mathrm{C} 6-\mathrm{P} 3$ vectors are staggered by $38.2^{\circ}$. The $\mathrm{P} 2-\mathrm{Cu}-\mathrm{P} 3$ bite angle of $112.14(4)^{\circ}$ is comparable with that of $109.31(2)^{\circ}$ in $\left[\mathrm{Cu}(\mathrm{dppf})\left(\mathrm{PPh}_{2} \mathrm{C}_{6} \mathrm{H}_{4} \mathrm{CHO}\right)\right]^{+}[18]$. On the basis of the solid structure, the major isomer of $\mathbf{4}$ in solution (Fig. 7) may have the two $\mathrm{Cu}(\mathrm{dppf})^{+}$groups in an anti position, and the minor isomer has the two $\mathrm{Cu}(\mathrm{dppf})^{+}$groups in a gauche position, by projection down the P1-P1A axis.

In conclusion, we have prepared several dinuclear copper(I) complexes with one to three dppa bridges. Compounds 1 and 2 contain a helical $\mathrm{Cu}_{2}(\mathrm{dppa})_{3}$ structure, compound 3 forms a $\mathrm{Cu}_{2}(\mathrm{dppa})_{2}$ metallacycle, and compound 4 has a linear $\mathrm{Cu}_{2}(\mathrm{dppa})$ skeleton. The $\mathrm{Cu} \cdots \mathrm{Cu}$ distance is $6.25 \AA$ for $1,6.19 \AA$ for $2,6.29 \AA$ for 3 and $7.78 \AA$ for 4 . It is promising that, by reacting with non-chelating agents such as $4,4^{\prime}$-bipyridine, the oligomer or polymer of 1 might be assembled. The investigation is progressive in our laboratory.

\section{Experimental}

\subsection{General methods}

All manipulations were carried out under an atmosphere of purified dinitrogen with standard Schlenk techniques. $\left[\mathrm{Cu}(\mathrm{MeCN})_{4}\right]\left[\mathrm{BF}_{4}\right] \quad[25], \quad\left[\mathrm{Cu}(\mathrm{MeCN})_{4}\right]\left[\mathrm{O}_{3} \mathrm{SCF}_{3}\right] \quad[25]$, $\mathrm{Ph}_{2} \mathrm{PC} \equiv \mathrm{CPPh}_{2}$ [26] and 1,1'-bis(diphenylphosphino)ferrocene [27] were prepared as described in the literature. Di-2pyridyl ketone was purchased from Acros and used as received without further purification. Solvents were dried over appropriate reagents under dinitrogen and distilled immediately before use. Infrared spectra were recorded on a Hitachi I-2001 IR spectrometer. Fast-atom-bombardment (FAB) and electrospray ionization (ESI) mass spectra were recorded on a VG Blotch-5022 mass spectrometer and a Bruker APEX II mass spectrometer, respectively. ${ }^{1} \mathrm{H}$ and ${ }^{31} \mathrm{P}$ NMR spectra were obtained on a Varian Unity INOVA-500 spectrometer. Elemental analyses were performed at the National Chen-Kung University, Tainan, Taiwan.

\subsection{Preparation of 1}

$\left[\mathrm{Cu}\left(\mathrm{CH}_{3} \mathrm{CN}\right)_{4}\right]\left[\mathrm{BF}_{4}\right] \quad(85 \mathrm{mg}, \quad 0.27 \mathrm{mmol}) \quad$ and $\mathrm{Ph}_{2} \mathrm{PC} \equiv \mathrm{CPPh}_{2}(168 \mathrm{mg}, 0.43 \mathrm{mmol})$ were placed in an oven-dried $100 \mathrm{ml}$ Schlenk flask, equipped with a magnetic stir bar and a rubber serum stopper. Freshly distilled $\mathrm{CH}_{3} \mathrm{CN}(20 \mathrm{ml})$ was introduced into the flask via a syringe through the serum stopper. The mixture was stirred at room temperature for $18 \mathrm{~h}$ under dinitrogen. The solution was filtered, and the filtrate was concentrated to ca. $5 \mathrm{ml}$ under vacuum. Diethyl ether $(15 \mathrm{ml})$ was then carefully added to afford air-stable, colorless crystals of $\left[\mathrm{Cu}_{2}(\mathrm{dp}\right.$ pa) $\left.)_{3}\left(\mathrm{CH}_{3} \mathrm{CN}\right)_{2}\right]\left[\mathrm{BF}_{4}\right]_{2}(\mathbf{1})(197 \mathrm{mg}, 0.126 \mathrm{mmol}, 93 \%$ based on $\mathrm{Cu}$ atoms). Anal. Calc. for $\mathrm{C}_{82} \mathrm{H}_{66} \mathrm{~B}_{2} \mathrm{Cu}_{2} \mathrm{~F}_{8} \mathrm{~N}_{2} \mathrm{P}_{6}$ : C, $62.89 ; \mathrm{H}, 4.25 ; \mathrm{N}, 1.79$. Found: $\mathrm{C}, 62.71 ; \mathrm{H}, 4.15 ; \mathrm{N}$, 
1.70\%. Mass (FAB): $\left.m / z 654\left(\left[\mathrm{Cu}_{2}(\mathrm{dppa})_{3}\right]\right]^{2+} ;{ }^{63} \mathrm{Cu}\right) .{ }^{1} \mathrm{H}$ NMR $\left(\mathrm{CD}_{2} \mathrm{Cl}_{2}, 20^{\circ} \mathrm{C}\right): \delta 7.43-7.11(\mathrm{~m}, 60 \mathrm{H}, \mathrm{Ph}), 2.61(\mathrm{~s}$, $\left.6 \mathrm{H}, \mathrm{CH}_{3} \mathrm{CN}\right) \cdot{ }^{31} \mathrm{P}\left\{{ }^{1} \mathrm{H}\right\}$ NMR $\left(\mathrm{CD}_{2} \mathrm{Cl}_{2}, 20{ }^{\circ} \mathrm{C}\right): \delta-26.70$ (br).

\subsection{Preparation of 2}

$\left[\mathrm{Cu}\left(\mathrm{CH}_{3} \mathrm{CN}\right)_{4}\right]\left[\mathrm{O}_{3} \mathrm{SCF}_{3}\right] \quad(150 \mathrm{mg}, \quad 0.398 \mathrm{mmol})$ and $\mathrm{Ph}_{2} \mathrm{PC} \equiv \mathrm{CPPh}_{2}(240 \mathrm{mg}, 0.61 \mathrm{mmol})$ were placed in an oven-dried $100 \mathrm{ml}$ Schlenk flask, and freshly distilled dichloromethane $(30 \mathrm{ml})$ was introduced into the flask via a syringe. The mixture was stirred at room temperature for $14 \mathrm{~h}$ and then filtered. The filtrate was concentrated under vacuum to ca. $5 \mathrm{ml}$ and diethyl ether $(20 \mathrm{ml})$ was added to produce air-stable, colorless crystals of $\mathrm{Cu}_{2}(\mathrm{dppa})_{3^{-}}$ $\left(\mathrm{O}_{3} \mathrm{SCF}_{3}\right)_{2}$ (2) (315 mg, 98\%). Anal. Calc. for $\mathrm{C}_{80} \mathrm{H}_{60} \mathrm{Cu}_{2-}$ $\mathrm{F}_{6} \mathrm{O}_{6} \mathrm{P}_{6} \mathrm{~S}_{2}: \mathrm{C}, 59.74 ; \mathrm{H}, 3.76$. Found: $\mathrm{C}, 59.76 ; \mathrm{H}, 3.82 \%$. Mass (ESI): $m / z 1457\left(\mathrm{M}^{+}-\mathrm{O}_{3} \mathrm{SCF}_{3} ;{ }^{63} \mathrm{Cu}\right)$. IR $(\mathrm{KBr}$, $\mathrm{cm}^{-1}$ ): 3057, 1481, 1436, 1306, 1234, 1213, 1166, 1097, 1024, 998, 918, 839, 740, 692, 635. ${ }^{1} \mathrm{H}$ NMR $\left(\mathrm{CD}_{2} \mathrm{Cl}_{2}\right.$, $\left.20{ }^{\circ} \mathrm{C}\right): \delta 7.55-7.08(\mathrm{~m}, \mathrm{Ph}) .{ }^{31} \mathrm{P}\left\{{ }^{1} \mathrm{H}\right\}$ NMR $\left(\mathrm{CD}_{2} \mathrm{Cl}_{2}\right.$, $\left.20^{\circ} \mathrm{C}\right): \delta-28.21$.

\subsection{Preparation of 3}

Compound 1 ( $25 \mathrm{mg}, 0.015 \mathrm{mmol}$ ), di-2-pyridyl ketone $(7 \mathrm{mg}, 0.038 \mathrm{mmol})$ and dichloromethane $(10 \mathrm{ml})$ were placed in an oven-dried $100 \mathrm{ml}$ Schlenk flask. The mixture was stirred at room temperature for $8 \mathrm{~h}$ to result in a clear yellow solution. Diethyl ether $(20 \mathrm{ml})$ was then introduced to afford air-stable, bright yellow crystals of $\left[\mathrm{Cu}_{2}(\mathrm{dppa})_{2}(\mathrm{~d}-\right.$ pyk $\left.)_{2}\right]\left[\mathrm{BF}_{4}\right]_{2}$ (3) $(22.4 \mathrm{mg}, 97 \%)$ at ambient temperature. Anal. Calc. for $\mathrm{C}_{74} \mathrm{H}_{56} \mathrm{Cu}_{2} \mathrm{~N}_{4} \mathrm{O}_{2} \mathrm{P}_{4} \mathrm{~B}_{2} \mathrm{~F}_{8}: \mathrm{C}, 60.97 ; \mathrm{H}, 3.87$; $\mathrm{N}$, 3.84. Found: $\mathrm{C}, 60.64 ; \mathrm{H}, 3.92 ; \mathrm{N}, 3.98 \%$. Mass (FAB): $m / z 641\left(\left[\mathrm{Cu}_{2}(\mathrm{dppa})_{2}(\mathrm{dpyk})_{2}\right]^{2+},{ }^{63} \mathrm{Cu}\right) .{ }^{1} \mathrm{H}$ NMR $\left(\mathrm{CD}_{2} \mathrm{Cl}_{2},-50^{\circ} \mathrm{C}\right): \delta 8.20\left(\mathrm{~d}, 4 \mathrm{H}, J_{\mathrm{H}-\mathrm{H}}=8 \mathrm{~Hz}, \mathrm{Py}\right), 8.05$ $\left(\mathrm{t}, 4 \mathrm{H}, J_{\mathrm{H}-\mathrm{H}}=8 \mathrm{~Hz}, \mathrm{Py}\right), 7.99\left(\mathrm{~d}, 4 \mathrm{H}, J_{\mathrm{H}-\mathrm{H}}=5 \mathrm{~Hz}, \mathrm{Py}\right)$, $7.48\left(\mathrm{t}, 16 \mathrm{H}, J_{\mathrm{H}-\mathrm{H}}=7 \mathrm{~Hz}, o-\mathrm{Ph}\right), 7.25-7.14(\mathrm{~m}, 24 \mathrm{H}$, $m, p-\mathrm{Ph}), 7.12\left(\mathrm{t}, 4 \mathrm{H}, J_{\mathrm{H}-\mathrm{H}}=5 \mathrm{~Hz}, \mathrm{Py}\right),{ }^{13} \mathrm{C}\left\{{ }^{1} \mathrm{H}\right\}\left(\mathrm{CD}_{2} \mathrm{Cl}_{2}\right.$, $\left.-70{ }^{\circ} \mathrm{C}\right): \delta 172.9(\mathrm{C}=\mathrm{O}), 142.2(C-\mathrm{CO}), 139.1,129.8$ (Py), 121.2, 121.1, 119.3 (Ph), 118.4, 117.7 (Py), 117.7 (d, $\left.J_{\mathrm{P}-\mathrm{C}}=42 \mathrm{~Hz}, \quad \mathrm{P}-\mathrm{C}_{(\mathrm{Ph})}\right), \quad 91.4 \quad(\mathrm{C} \equiv) . \quad{ }^{31} \mathrm{P}\left\{{ }^{1} \mathrm{H}\right\} \quad \mathrm{NMR}$ $\left(\mathrm{CD}_{2} \mathrm{Cl}_{2}, 20^{\circ} \mathrm{C}\right): \delta-24.64$ (br).

\subsection{Preparation of 4}

Compound $1 \quad(25 \mathrm{mg}, \quad 0.015 \mathrm{mmol}), \quad 1,1^{\prime}$-bis(diphenylphosphino)ferrocene $(23 \mathrm{mg}, 0.041 \mathrm{mmol})$ and dichloromethane $(8 \mathrm{ml})$ were placed in an oven-dried $100 \mathrm{ml}$ Schlenk flask. The solution was stirred at room temperature for $8 \mathrm{~h}$ and filtered. Diethyl ether $(15 \mathrm{ml})$ was added to give air-stable, orange crystals of $\left[\mathrm{Cu}_{2}(\mathrm{dppa})\right.$ $\left.(\mathrm{dppf})_{2}\right]\left[\mathrm{BF}_{4}\right]_{2}$ (4) $(24 \mathrm{mg}, \quad 85 \%)$. Anal. Calc. for $\mathrm{C}_{94} \mathrm{H}_{76} \mathrm{Cu}_{2} \mathrm{~B}_{2} \mathrm{~F}_{8} \mathrm{Fe}_{2} \mathrm{P}_{6}$ : C, 62.59; $\mathrm{H}$, 4.25. Found: $\mathrm{C}$, 62.38; H, 4.62\%. Mass (ESI): $m / z 1011$ ([Cu(dppa)(dppf) ], $\left.{ }^{63} \mathrm{Cu}\right)$. IR $\left(\mathrm{KBr}, \mathrm{cm}^{-1}\right): 3052,1480,1436,1308,1166,1094$, $1028,842,832,742,692,630,556,506,482 .{ }^{1} \mathrm{H}$ NMR $\left(\mathrm{CD}_{2} \mathrm{Cl}_{2}, 20^{\circ} \mathrm{C}\right): \delta 7.45-7.26(\mathrm{~m}, 60 \mathrm{H}, \mathrm{Ph}), 4.37(\mathrm{~d}, 8 \mathrm{H}$, $\left.J_{\mathrm{H}-\mathrm{H}}=9 \mathrm{~Hz}, \mathrm{Cp}\right), 4.14\left(\mathrm{~d}, 8 \mathrm{H}, J_{\mathrm{H}-\mathrm{H}}=9 \mathrm{~Hz}, \mathrm{Cp}\right) \cdot{ }^{31} \mathrm{P}\left\{{ }^{1} \mathrm{H}\right\}$ NMR $\left(\mathrm{CD}_{2} \mathrm{Cl}_{2}, 20^{\circ} \mathrm{C}\right): \delta-10.4$ (br, dppf), -31.0 (br, dppa); $\left(-35^{\circ} \mathrm{C}\right): \delta-7.78,-13.29$ (dppf), $-25.15,-33.03$ (dppa).

\subsection{Structure determination for $\mathbf{1}-\mathbf{4}$}

A crystal of 1 (ca. $0.35 \times 0.30 \times 0.30 \mathrm{~mm}), \quad 2$ (ca. $0.25 \times 0.25 \times 0.20 \mathrm{~mm}$ ), 3 (ca. $0.25 \times 0.20 \times 0.20 \mathrm{~mm}$ ) and 4 (ca. $0.20 \times 0.20 \times 0.15 \mathrm{~mm}$ ) was each mounted in a thinwalled glass capillary and aligned on the Bruker SMART Apex CCD (for 3 and 4) or the Nonius Kappa CCD (for 1 and 2) diffractometer with graphite-monochromated Mo $\mathrm{K} \alpha$ radiation $(\lambda=0.71073 \AA)$. The maximum $2 \theta$ angle for data collection is $27.50^{\circ}$ for all compounds. Of the $51391,40329,24586$ and 42348 reflections collected for 1, 2, 3 and 4, 18202, 8504, 8536 and 9857 reflections were independent, respectively. All data were corrected for Lorentz and polarization effects and for the effects of absorption. The structure was solved by the direct method

Table 1

Crystallographic data for compounds $\mathbf{1}-\mathbf{4}$

\begin{tabular}{lllll}
\hline & $\mathbf{1}$ & $\mathbf{2}$ & $\mathbf{3}$ & $\mathbf{4}$ \\
\hline Formula & $\mathrm{C}_{86} \mathrm{H}_{74} \mathrm{~B}_{2} \mathrm{Cu}_{2} \mathrm{~F}_{8} \mathrm{~N}_{2} \mathrm{OP}_{6}$ & $\mathrm{C}_{80} \mathrm{H}_{60} \mathrm{Cu}_{2} \mathrm{~F}_{6} \mathrm{O}_{6} \mathrm{P}_{6} \mathrm{~S}_{2}$ & $\mathrm{C}_{76} \mathrm{H}_{60} \mathrm{~B}_{2} \mathrm{Cl}_{4} \mathrm{Cu}_{2} \mathrm{~F}_{8} \mathrm{~N}_{4} \mathrm{O}_{2} \mathrm{P}_{4}$ & $\mathrm{C}_{96} \mathrm{H}_{80} \mathrm{~B}_{2} \mathrm{Cl}_{4} \mathrm{Cu}_{2} \mathrm{~F}_{8} \mathrm{Fe}_{2} \mathrm{P}_{6}$ \\
Formula weight & 1637.99 & 1608.30 & 1627.66 & 1973.62 \\
Crystal system & triclinic & tetragonal & triclinic & monoclinic \\
Space group & $P \overline{1}$ & $P 4_{3} 2_{1} 2$ & $P \overline{1}$ & $P 2_{1} / c$ \\
$a(\AA)$ & $13.5675(2)$ & $14.9771(1)$ & $10.8918(6)$ & $12.3200(4)$ \\
$b(\AA)$ & $16.4722(2)$ & $14.9771(1)$ & $14.2601(8)$ & $24.6772(7)$ \\
$c(\AA)$ & $18.6473(3)$ & $32.9919(4)$ & $14.4502(8)$ & $14.2431(4)$ \\
$\alpha\left({ }^{\circ}\right)$ & $98.14(3)$ & 90 & $118.967(1)$ & 90 \\
$\beta\left({ }^{\circ}\right)$ & $91.4014(9)$ & 90 & $96.586(1)$ & $96.538(1)$ \\
$\gamma\left({ }^{\circ}\right)$ & $105.36(3)$ & 90 & $101.423(1)$ & 90 \\
$V\left(\AA^{3}\right)$ & $3969.7(1)$ & $7400.53(1)$ & $1865.8(2)$ & $4302.1(2)$ \\
$T(\mathrm{~K})$ & $150(1)$ & $150(1)$ & $150(1)$ & $150(1)$ \\
$Z$ & 2 & 4 & 1 & 2 \\
$\mu\left(\mathrm{mm}^{-1}\right)$ & 0.723 & 0.829 & 0.868 & 1.120 \\
Final $R_{1} / w R_{2}$ & $0.0590 / 0.1513$ & $0.0332 / 0.0694$ & $0.0492 / 0.1329$ & $0.0727 / 0.1710$ \\
\hline
\end{tabular}


and refined by full-matrix least-squares on $F^{2}$. The nonhydrogen atoms were refined anisotropically. Hydrogen atoms were included with a riding model. All calculations were performed using the SHELXTL-97 package [28]. The data collection and refinement parameters are presented in Table 1.

\section{Acknowledgement}

We are grateful for the support of this work by the National Science Council of Taiwan.

\section{Appendix A. Supplementary material}

Crystallographic data for $\mathbf{1 - 4}$ have been deposited with the Cambridge Crystallographic Data Centre, deposition numbers CCDC 287403-287406. Copies of these data may be obtained free of charge from The Director, CCDC, 12 Union Road, Cambridge CB2 1EZ, UK. Supplementary data associated with this article can be found, in the online version, at doi:10.1016/j.ica.2006.02.038.

\section{References}

[1] M. Fujita, Chem. Soc. Rev. (1998) 417.

[2] S. Leininger, B. Olenyuk, P.J. Stang, Chem. Rev. 100 (2000) 853

[3] L. Brammer, Chem. Soc. Rev. 33 (2004) 476.

[4] P.J. Steel, Acc. Chem. Res. 38 (2005) 243.

[5] M. Ruben, J. Rojo, F.J. Romero-Salguero, L.H. Uppadine, J.-M. Lehn, Angew. Chem., Int. Ed. 43 (2004) 3644.

[6] J.W. Steed, J.L. Atwood, Supramolecular Chemistry, Wiley, New York, 2000
[7] R.H. Holm, P. Kennepohl, E.I. Soloman, Chem. Rev. 96 (1996) 2239.

[8] T.R. Demmin, M.D. Swerdloff, M.M. Rogić, J. Am. Chem. Soc. 103 (1981) 5795 .

[9] S. ItohComprehensive Coordination Chemistry II, vol. 8, Elsevier, Oxford, UK, 2004, p. 369.

[10] R.H. Crabtree, The Organometallic Chemistry of the Transition Metals, 3rd ed., Wiley, New York, 2001.

[11] B.F.G. Johnson, J. Lewis, A.D. Massey, P.R. Raithby, W.T. Wong, J. Organomet. Chem. 397 (1990) C28

[12] E. Louattani, J. Suades, J. Organomet. Chem. 604 (2000) 234.

[13] L.R. Falvello, J. Forniés, J. Gómez, E. Lalinde, A. Martín, F. Martínez, M.T. Moreno, J. Chem. Soc., Dalton Trans. (2001) 2132.

[14] G. Hogarth, T. Norman, Polyhedron 15 (1996) 2859.

[15] O. Orama, J. Organomet. Chem. 314 (1986) 273.

[16] W.-Y. Yeh, S.-M. Peng, G.-H. Lee, J. Organomet. Chem. 671 (2003) 145 .

[17] A. Baiada, F.H. Jardine, R.D. Willett, K. Emerson, Inorg. Chem. 30 (1991) 1365.

[18] W.-Y. Yeh, Y.-C. Liu, S.-M. Peng, G.-H. Lee, Inorg. Chim. Acta 358 (2005) 1987.

[19] A.J. Carty, A. Efraty, T.W. Ng, Can. J. Chem. 47 (1969) 1429.

[20] M. Semmelmann, D. Fenske, J.F. Corrigan, J. Chem. Soc., Dalton Trans. (1998) 2541.

[21] A.I. Wallbank, J.F. Corrigan, Can. J. Chem. 80 (2002) 1592.

[22] S.L. James, E. Lozano, M. Nieuwenhuyzen, Chem. Commun. (2000) 617.

[23] M. Bardají, M.T. de la Cruz, P.G. Jones, A. Laguna, J. Martínez, M.D. Villacampa, Inorg. Chim. Acta 358 (2005) 1365.

[24] R.S. Drago, Physical Methods for Chemists, 2nd ed., Saunders College Publishing, New York, 1992.

[25] G.J. Kubas, Inorg. Synth. 19 (1979) 90.

[26] D.R.M. Walton, F. Waugh, J. Organomet. Chem. 45 (1972) 45.

[27] I.R. Butler, Inorganic Experiments, VCH, Weinheim, Germany, 1994.

[28] G.M. Sheldrick, SheLXTL-97, University of Göttingen, Germany, 1997. 